phenformin concentration correspondingly increased in patients with plasma creatinine levels of 2 to $3 \mathrm{mg} / 100 \mathrm{ml}$ or more (Tranquada et al., 1963). Thus renal damage could trigger a vicious circle and lead to a gradually developing metabolic acidosis. The lactic acidosis discussed in connexion with reduced renal function could then be the end stage. Unfortunately, little information is available about the early metabolic acidosis in cases that develop lactic acidosis.

\section{References}

Aber, S. M., Morris, L. O., and Hously, E. (1966). Nature, 212, 1589.
Alleyne, G. A. O., Besterman, H. S., and Flores, H. (1971). Clinical Science, $40,107$.

Alleyne, G. A. O., and Scullard, G. H. (1969). Fournal of Clinical Investigation, 48, 364 .

Bengtsson, K., Karlberg, B., and Lindgren, S. (1972). Acta Medica Scandinavica, 191, 203

Gordon, E. E., and de Hartog, M. (1973). Diabetes, 22, 50.

Kildeberg, P. (1968). |Clinical Acid-base Physiology. Copenhagen, Munksgaard. Searle, G. L., et al. (1966). Diabetes, 15, 173

Tranquada, R. E., Bernstein, S., and Martin, H. E. (1963). Fournal of the American Medical Association, 184, 37.

Varma, S. K., Heaney, S. J., Whyte, W. C., and Walker, R. S. (1972). British Medical fournal, i, $20 \overline{5}$.

Williamson, D. H., Mellanby, J., and Krebs, H. A. (1962). Biochemical Fournal, 82, 90.

Wrong, O., and Davies, H. E. F. (1959). Quarterly fournal of Medicine, 28, 259.

\title{
Different Effects of Adrenergic Beta-receptor Blockade on Heart Rate Response to Mental Stress, Catecholamines, and Exercise
}

\author{
S. H. TAYLOR, M. K. MEERAN
}

British Medical fournal, 1973, 4, 257-259

\section{Subjects and Method}

Studies were made on six normal men, aged 26-47 years. None had any symptoms of systemic disease, none were obese, and in all the blood pressure was within normal limits. Two subjects were the authors; the remainder were professional colleagues who fully understood the aims and nature of the investigation.

The magnitude and duration of effect of a single $40-\mathrm{mg}$ oral tablet of oxprenolol on the tachycardias associated with motor-car driving, isoprenaline infusion, and walking were compared against placebo in six normal people by a double-blind study. The tachycardias due to driving and isoprenaline were both conspicuousy reduced for over eight hours; the magnitude and duration of the reduction in exercise tachycardia was substantially less. Thus relatively small doses of beta-receptor antagonists will suppress the increase in heart rate induced by mental stress or catecholamines with relatively little effect on the response to everyday exercise. Possibly smaller doses of these drugs would relieve emotionallyinduced anginal pain and tachycardia.

\section{Introduction}

Emotional stress, catecholamines, and physical exertion all induce an increase in heart rate. During recent studies of the effects of environmentally-induced psychological stress on the heart it was noticed that small doses of the beta-receptor antagonist oxprenolol had conspicuously greater effect on the tachycardia associated with mental stress than on the heart rate increase during walking. In view of the possible therapeutic implications of this observation the following study was designed to define more closely the quantitative relation between the tachycardias due to these three stimuli in terms of their inhibition by beta-receptor antagonists.

\footnotetext{
Cardiovascular Unit, University Department of Medicine, The General Infirmary, Leeds LS1 3EX

S. H. TAYLOR, M.B., F.R.C.P., Senior Lecturer in Medicine, Consultant Physician, and Deputy Director, Cardiovascular Unit

M. K. MEERAN, M.R.C.P., F.C.P.(S.A.), Senior Ciha Research Fellow and Honorary Lecturer in Medicine
}

\section{DESIGN OF STUDY}

The heart rate was measured from an electrocardiographic record in each subject in the following three situations. (1) Driving a motor-car for 15-20 minutes in heavy city traffic. (2) In the supine position during a two-minute intravenous isoprenaline infusion sufficient to raise the heart rate to the levels observed during driving. (3) During treadmill walking of two minutes' duration sufficient to raise the heart rate to similar levels.

Preliminary studies were carried out to familiarize each subject with the programme of investigation and determine the peak heart rate response regularly achieved by motor-car driving.in city traffic; the dose of intravenous isoprenaline and level of treadmill walking necessary to give similar heart rate increases were then determined. Motor-car driving carried out over a random route through Leeds city centre for 15-20 minutes repeatedly resulted in peak heart rate increments of 30 beats/min or more in all subjects. A similar increase in heart rate was induced by treadmill walking at 3 m.p.h. ( 5 k.p.h.) on a $10-15^{\circ}$ incline for two minutes.

The definitive double-blind studies were begun at 8.00 a.m., two hours after a light breakfast and one hour after a single oral tablet of $40 \mathrm{mg}$ oxprenolol or a matched placebo tablet of sucrose and starch. A control electrocardiogram was recorded with each subject sitting quietly at the wheel of his car. A 15-20 minute period of city driving was then undertaken on a random route selected by the monitoring observer travelling as a passenger. The subject then returned to the laboratory and, after 10 minutes' rest, a two-minute intravenous infusion of isoprenaline was given in a dose that had been determined beforehand would raise the heart rate in that subject by about 30 beats $/ \mathrm{min}$. After a further 10 minutes' rest, by which time the heart rate had returned to preisoprenaline infusion levels in all subjects, the treadmill walking test was performed. Similar studies were 
repeated at $2,4,6,8,12$, and 24 hours. The programme was repeated three or four days later after taking the remaining placebo or oxprenolol tablet; the order of tablet administration was randomized.

Between the test periods each subject returned to his normal professional duties. No restriction was placed on their activities except that they were required not to eat large meals or smoke within an hour of the subsequent test.

Active and placebo tablets were coded in pairs for each subject.

\section{TECHNIQUES, MEASUREMENTS, AND STATISTICS}

Heart rate was measured from an electrocardiographic record taken during the last 10 seconds of each minute of the study and counted and checked by two colleagues not involved in the study. The electrocardiogram was recorded with adhesive disc silver chloride electrodes (Becton Dickinson, Ltd.) from chest lead V5 with stabilizing limb leads placed below the right and left clavicles and in the right and left hypochondrium. The separate leads were taped to the shaved skin and led into a small 5-pin plug clipped to the subject's waistband. For recording, an extensible lead was connected to a portable electrocardiograph (Cambridge Instrument Co., Transrite Model III). Records were calibrated externally $(0 \cdot 1 \mathrm{mV}=1 \mathrm{~mm})$. The electrodes remained in position throughout each 12-hour test. This method of E.C.G. recording is comfortable and discrete, it does not restrict normal everyday activities, including driving, and the subject rapidly becomes unaware of the presence of the electrodes. Furthermore, the method has the essential advantage that it allows stable E.C.G. records to be obtained during treadmill exercise. During the 15-minute motor-car drive E.C.G. records were made in the last 10 seconds of each minute and an average heart rate was calculated for each 10-second period. The highest heart rate recorded during the 15-minute drive was used for the subsequent comparison. The heart rate was similarly measured and averaged during the last 10 seconds of the isoprenaline infusion and during the last 10 seconds of the second minute of exercise.

Isoprenaline (Evans Medical, Ltd.) was given as a continuous intravenous infusion into a hand or arm vein via a subcutaneous needle by an electromechanical pump (Harvard Model 901) with a variation in rate of less than $2 \%$ of the predicted minute volume. The concentration was arranged so that the volume of fluid infused was between 2 and $5 \mathrm{ml} / \mathrm{min}$. Walking was carried out on a treadmill (Quinton Instruments, Model 18-54); all subjects were familiar with this form of exercise. Subjects drove their own motor-cars, which all had manual gear boxes.

The variability of the response to the test was calculated in each subject from the placebo results as a percentage of the mean (S.E. of mean $/$ mean $\times 100$ ), and averaged for the group. Increments in heart rate during the placebo and drug studies were averaged for all subjects at each hour of the test; the probability of statistical significance of differences between the placebro and drug results were calculated from paired samples.

\section{Results}

A summary of the effects of $40 \mathrm{mg}$ oral oxprenolol compared with placebo on the heart rate response to motor-car driving, isoprenaline infusion, and treadmill walking in six normal subjects are presented in the graph and table. During the placebo studies the average variability of the heart rate response to driving, isoprenaline, and exercise was $10 \%$ (range 3.8-13.8), $3 \%$ (range $3 \cdot 1-3 \cdot 9$ ), and $3 \%$ (range $3 \cdot 0-3 \cdot 4$ ) respectively. Compared with the results with placebo, the tachycardia associated with motor-car driving and isoprenaline infusion was conspicuously reduced for up to 12 hours after $40 \mathrm{mg}$ oral oxprenolol. In the same subjects the drug had much less effect on the heart rate response to treadmill walking.

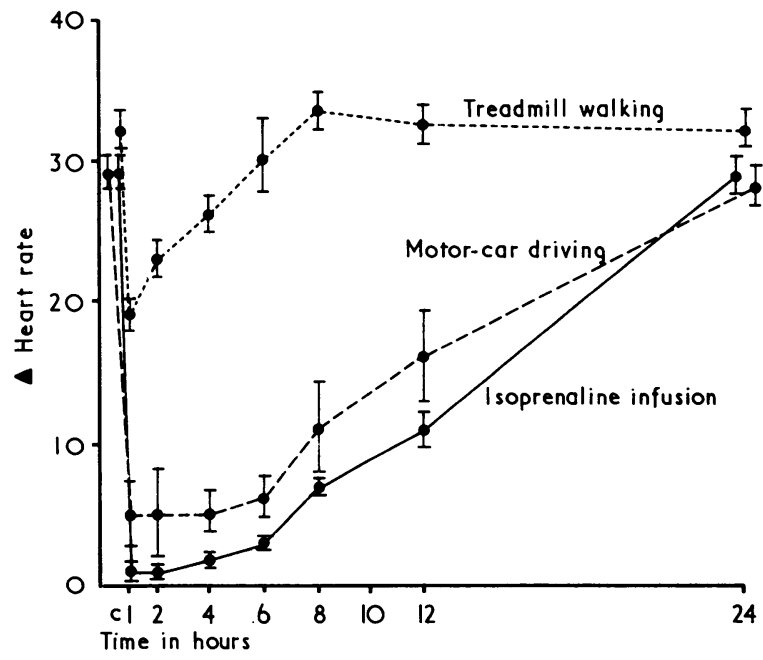

Effect of $40 \mathrm{mg}$ oral oxprenolol on the heart rate increase (A Heart Rate) during motor-car driving, isoprenaline infusion, and treadmill walking in six normal subjects. The control values (c) are the average of the increases in heart rate measured throughout the day on placebo. Data expressed as mean of observations $\pm S$.E. of mean.

\section{Discussion}

These results clearly show the different effects of a similar degree of beta-receptor blockade on the increases in heart rate associated with mental stress and catecholamine infusion compared with the effect on a similar tachycardia induced by

Effect of Beta-adrenoreceptor Inhibition on Tachycardia Associated with Motor-car Driving, Catecholamine Infusion, and Treadmill Walking in Six Normal Subjects (Results expressed as Mean \pm S.E. of Mean)

\begin{tabular}{|c|c|c|c|c|c|c|c|c|c|}
\hline & \multirow{2}{*}{$\begin{array}{c}\text { Heart Rate } \\
\text { During Control } \\
\text { Periods } \\
\end{array}$} & \multicolumn{7}{|c|}{ Increase in Heart Rate over Control Value After Placebo or Oxprenolol at: } & \multirow{2}{*}{$\begin{array}{l}\text { Average Incre- } \\
\text { ment over } \\
\text { Control Value }\end{array}$} \\
\hline & & $1 \mathrm{hr}$ & $2 \mathrm{hr}$ & $4 \mathrm{hr}$ & $6 \mathrm{hr}$ & $8 \mathrm{hr}$ & $12 \mathrm{hr}$ & $24 \mathrm{hr}$ & \\
\hline $\begin{array}{l}\text { Motor-car driving: } \\
\text { Placebo }\end{array}$ & $71 \pm 2$ & $34 \pm 3$ & $29 \pm 3$ & $25 \pm 2$ & $30 \pm 3$ & $27 \pm 2$ & $28 \pm 3$ & $30 \pm 3\} N$ & $29 \pm 1$ \\
\hline $\begin{array}{l}\text { Oxprenolol } \\
\text { Isoprenaline }\end{array}$ & $63 \pm 2$ & $5 \pm 2$ & $5 \pm 3$ & $5 \pm 1$ & $6 \pm 1$ & $11 \pm 3$ & $16 \pm 3$ & $28 \pm 3 \int$ & - \\
\hline $\begin{array}{l}\text { infusion: } \\
\text { Placebo }\end{array}$ & $68 \pm 1$ & $29 \pm 1$ & $31 \pm 2$ & $30 \pm 1$ & $27 \pm 1$ & $29 \pm 1$ & $32 \pm 1$ & $30 \pm 2\} N$ & $29 \pm 1$ \\
\hline $\begin{array}{l}\text { Oxprenolol } \\
\text { Treadmill Walking: }\end{array}$ & $61 \pm 1$ & $1 \pm 0$ & $1 \pm 0$ & $2 \pm 0$ & $3 \pm 1$ & $7 \pm 2$ & $11 \pm 3$ & $29 \pm 2\}^{18}$ & - \\
\hline Placebo & $87 \pm 3$ & $32 \pm 1$ & $31 \pm 1$ & $33 \pm 1$ & $31 \pm 1\}$ N.S. & $32 \pm 2\}$ N.S. & $30 \pm 1\}$ N.S. & $31 \pm 1\}_{\text {N.S. }}$ & $32 \pm 1$ \\
\hline Oxprenolol & $71 \pm 2$ & $19 \pm 1$ & $23 \pm 1$ & $26 \pm 1$ & $30 \pm 2\}$ & $33 \pm 1\}$ & $32 \pm 2\}$ & $32 \pm 2\}$ & - \\
\hline
\end{tabular}


exercise. Their validity is emphasized by the double-blind method of study, the randomized order of placebo and drug administration, and the serial comparison of the effects of each in the three tests in each subject. These results agree with those of other uncontrolled studies of the effects of motor-car driving on the heart rate (Hoffman, 1965; Suenga, et al. 1965; Bellet et al., 1968; Simonson et al., 1968; Taggart et al., 1969; Littler et al., 1973); they also confirm the results of previous single-blind studies of the effects of beta-receptor antagonists on the heart rate response to environmentally-induced physchological stress (Eliasch et al., 1967; Taggart and Carruthers, 1972; Meeran and Taylor, 1973; Taylor and Meeran, 1973).

The exact mechanism by which mental stress induces an increase in heart rate is unknown; but the equal suppression of the tachycardia associated with motor-car driving and that due to infused catecholamines by the same degree of beta-receptor blockade suggests that both tachycardias are probably induced by a similar increase in concentration of catecholamines at the cardiac beta-receptor sites controlling the heart rate. Though it does not necessarily follow that there is a similar increase in level of circulating catecholamines, an increase in the concentration of plasma catecholamines has been observed in racing-car drivers in parallel with an increase in heart rate (Taggart and Carruthers, 1972). At extreme levels of exertion the increase in heart rate is predominantly due to direct sympathetic stimulation of the heart rate beta-receptors. But at the levels of exercise used in the present studies, with heart rates of $100-120$ beats per minute, the tachycardia is due both to sympathetic stimulation and vagal withdrawal (Robinson et al., 1966). In fact, the present results indicate that the degree of direct sympathetic activity concerned in the heart rate increase at this level of normal everyday exertion is probably small compared with the vagal withdrawal component. This is the most likely explanation for the different effects of small doses of beta-receptor antagonists on the heart rate response to the three stimuli observed in the present studies.

These findings have important clinical implications in the treatment of angina pectoris. One of the ideals of medical treatment is the establishment of a dose-response relation, with the corollary that only sufficient drug should be given as is necessary to achieve the desired therapeutic effect. Though the mechanisms responsible for precipitating anginal pain in susceptible subjects are unknown, the onset of pain is closely correlated with an increase in heart rate (Taylor, 1973), whether this be induced by exercise (Sharma and Taylor, 1973), catecholamine infusion (Wexler et al., 1971), or the mentally stressful activities of everyday life (Taggart et al., 1969; Taylor and Meeran, 1973). Our results suggest that the dose of betareceptor antagonists necessary to suppress the tachycardia in these different situations may differ widely. The single dose of oral or oxprenolol necessary to produce a near-maximum suppression of exercise tachycardia is $160 \mathrm{mg}$ (Taylor et al., 1973). Nevertheless, the maximum effectiveness of this dose in this respect is relatively short-lived and most anginal patients experience relief from exercise-induced symptoms only with repeated daily doses of this order (Prichard and Gillam, 1971). The present results suggest that the tachycardia and possibly the anginal pain associated with anxiety or emotion may be controlled by much smaller doses of drug than those necessary to afford relief during exercise.

These studies were undertaken as an essential preliminary to the investigation of the cardiac response to everyday mental stress and its modulation by beta-receptor antagonists. The results indicate that the increase in the heart rate associated with psychological stress may be largely suppressed during the day by a dose of beta-receptor antagonist that has been shown to have no discernible mental effects (Turner, 1973) and only small and relatively short-lasting effects on the heart rate response to walking.

We are grateful to our professional colleagues who volunteered as subjects for this study, and to those who assisted us by counting and checking the heart rate measurements. We also wish to thank Mr. M. Pearson, senior technician, for his valuable help.

M.K.M. is a Ciba Senior Research Fellow; this work formed part of a thesis presented for the degree of M.D. in the University of Natal, Republic of South Africa.

This work was supported by a grant from the West Riding Medical Research Trust.

Requests for reprints should be addressed to: Dr. S. H. Taylor, Department of Medicine, The General Infirmary, Leeds LS1 3EX.

\section{References}

Bellet, S., Roman, L., Kostis, J., and Slater, A. (1968). American fournal of Cardiology, 22, 856 .

Eliasch, H., Rosen, A., and Scott, H. M. (1967). British Heart Fournal, 29, 671.

Hoffman, H. (1965). Zeitschrift für Verkehrssicherheit, 11, 145.

Littler, W. A., Honour, A. J., and Sleight, P. (1973). British Medical Fournal, 2,273 .

Meeran, M. K., and Taylor, S. H. (1973). In preparation.

Prichard, B. N. C., and Gillam, P. M. S. (1971). British Heart Fournal, 33, 473.

Robinson, B. F., Epstein, S. E., Beiser, D. G., and Braunwald, E. (1966). Circulation Research, 19, 400.

Sharma, B., and Taylor, S. H. (1973). In preparation.

Simonson, E., et al. (1968). American Heart fournal, 75, 125

Simonson, E., et al. (1968). American Heart fournal, 75, 125. fournal of the Kurume Medical Association, 28, 1091.
.

Taggart, P., Gibbons, D., and Somerville, W. (1969). British Medical Fournal, 4, 130.

Taggart, P., and Carruthers, M. (1972). Lancet, 2, 256.

Taylor, S. H. (1973). In Mechanisms of Action of Adrenergic Beta-Receptor Antagonists in Angina Pectoris. Proceedings of Symposium New Perspectives in $\beta$-Blockade, Aarhus, Denmark, May, 1972.

Taylor, S. H., and Meeran, M. K. (1973). In Cardiovascular Response to Some Environmental Stresses and their Modification by Oxprenolol. Proceedings of Symposium New Perspectives in $\beta$-Blockade, Aarhus, Denmark, May, 1972.

Taylor, S. H., Davidson, C., Thadani, U., and Myint, S. (1973). In pre-

paration.
Turner, P. (1973). In An Investigation of the Central Effects of Oxprenolol Proceedings of Symposium New Perspectives in $\beta$-Blockade, Aarhus, Proceedings of Symposit

Wexler, H., Kuaity, J., and Simonson, E. (1971). British Heart fournal, 33, 759. 